\title{
Bacterial hopanoids from pink-pigmented facultative methylotrophs (PPFMs) and from green plant surfaces
}

\author{
M'hamed Knani, ${ }^{1}$ William A. Corpe ${ }^{2}$ and Michel Rohmer'
}

Author for correspondence: Michel Rohmer.

\footnotetext{
1 Laboratoire de Chimie Microbienne, CNRS-URA 135, Ecole Nationale Supérieure de Chimie de Mulhouse, Université de Haute Alsace, 3 rue Alfred Werner, 68093 Mulhouse Cedex, France

2 Department of Biological Sciences, Columbia University in the City of New York, New York, NY 10027, USA
}

\begin{abstract}
Six strains of pink-pigmented facultatively methylotrophic bacteria (PPFMs) isolated from phylloplane surfaces of different plants were analysed for the presence of triterpenoids of the hopane series. All of the cultures produced hopanoids in abundant quantities and contained the same compounds as the type strain of Methylobacterium organophilum : diplopterol, $2 \beta$ methyldiplopterol, bacteriohopanetetrol, a tetrol glycoside and two tetrol ethers. The presence of a guanidinium group on the carbapseudopentose moiety of one of these ethers and/or of $2 \beta$-methyldiplopterol seems to be restricted to the genus Methylobacterium. Small amounts of bacteriohopanepolyols were detected in three of seven plants studied. Since no bacterial $C_{35}$ hopanoids have been reported in eukaryotes, we believe they are probably derived from eubacterial epibionts present on the phylloplane surfaces, the most numerous of which are Methylobacterium spp.
\end{abstract}

Keywords: hopanoids, isoprenoids, Metbylobacterium, PPFMs, phylloplane

\section{INTRODUCTION}

Triterpenoids of the hopane series were first revealed by the wide distribution of their molecular fossils (Ourisson et al., 1979) and they are considered important constituents of prokaryotes. They have been found in Gram-negative and Gram-positive bacteria scattered through numerous eubacterial taxonomic groups (Rohmer et al., 1984). The ability to synthesize hopanoids may be interesting for taxonomic reasons, but the number of strains analysed to date is too restricted to draw any definitive conclusions about the importance of hopanoids in bacterial taxonomy. Typical triterpenoids of this class are bacteriohopanepolyols. Their structure derives from the hopane skeleton linked to a $C_{5}$ n-alkyl polyhydroxylated sidechain derived from a D-pentose (Flesch \& Rohmer, 1988; Rohmer et al., 1989).

The pink-pigmented facultative methylotrophs (PPFMs) are ubiquitous $\mathrm{Gram}$-negative bacteria, widely distributed in nature and regularly isolated from plant surfaces (Corpe, 1985). They have been assigned to species of the genus Metbylobacterium (Green et al., 1988). PPFMs grow on a variety of carbon sources (Green \& Bousfield, 1982; Corpe \& Basile, 1982) and possess great metabolic versatility. This has proved useful for the incorporation of

Abbreviation: PPFM, pink-pigmented facultative methylotroph.
${ }^{13} \mathrm{C}$-labelled precursors in order to elucidate a novel nonmevalonate pathway for isoprenoid biosynthesis in eubacteria (Flesch \& Rohmer, 1988; Rohmer et al., 1993). In the course of our hopanoid screening, it appeared interesting to examine PPFMs isolated from plant sources and to compare their hopanoids for qualitative similarity with those from Metbylobacterium organophilum (Renoux \& Rohmer, 1985) and from whole-plant material, thus providing a basis for a specific chemical signature of bacterial epibionts.

\section{METHODS}

PPFM strains and cultivation. The PPFMs SAL (isolated from an aquatic fern and identified as Metbylobacterium fujisawaense by P. Green on the base of phenotype analysis), CONO (from a liverwort), MESO (Metbylobacterium mesophilicum, ATCC 29983, from rye grass), MIM-2 (from a mimosa), CM (from a liverwort) and PC 1 (from white clover) have been described in previous papers (Corpe \& Basile, 1982; Corpe et al., 1986; Corpe \& Rheem, 1989). In the present work, PPFMs, were usually grown on a modification of the medium of Hestrin \& Schramm (1954) in 2 litre Erlenmeyer flasks for $30 \mathrm{~h}$ at $30^{\circ} \mathrm{C}$ on rotatory tables. The SAL and CONO strains were also grown for biosynthetic studies on a synthetic ammonium/mineral salts medium supplemented with vitamins and using acetate or glucose as sole carbon source (Rohmer et al., 1993).

Plant material. Two samples of the aerial parts of the moss Abietinella abietina (Hedm.) Fleisch. were examined: the first one 
<smiles>CC(C)C1CCC23CCCC4C(C)CCC4[C@@]2(C)CCC1C3(C)C</smiles>

hopane<smiles>C=C(C)CCC</smiles>

I<smiles>CCC(C)(C)O</smiles>

II<smiles>CCC(C)CC[C@@H](O)[C@H](O)[C@H](O)CO</smiles>

IV

III $2 \beta$-methyl<smiles>[X][C@H]1C(O)C(O)C(O)(CO)C1OC[C@H](O)[C@@H](O)[C@@H](O)CCC(C)CCC</smiles>

$\mathrm{V} \quad \mathrm{X}=\mathrm{H}$

VI $X=-c^{\prime \prime}{ }^{\prime N H_{2}^{+}}$<smiles>CCC(C)CC[C@H](O)C(O)[C@H](O)CO[C@H]1O[C@H](CO)C(O)[C@@H](O)C1N</smiles>

VII

Fig. 1. Hopanoids from PPFMs.

(9 $\mathrm{g}$, dry weight) was collected near Osenbach, the second one ( $2.5 \mathrm{~g})$ near Village Neuf (both from Haut-Rhin, France). Leaves of the following plants were collected where indicated: Trifolium repens L. (white clover, $17 \mathrm{~g}$ ), Viola odorata (violet, $5.6 \mathrm{~g}$ ), Fragaria vesca $\mathrm{L}$. (wild strawberry, $9.5 \mathrm{~g}$ ) and Solanum lycopersicum L. (tomato, $14 \mathrm{~g}$ ) in gardens in Mulhouse (Haut-Rhin, France), and I'itis vinifera $\mathrm{L}$. leaves (vine, $6 \mathrm{~g}$ ) at the research station of the Institut National de la Recherche Agronomique (Colmar, Haut-Rhin, France). Amaryllis sp. leaves $(10 \mathrm{~g})$ came from an indoor-grown plant. All plant tissues were harvested at the end of August 1990 and were freeze-dried before extraction; they were healthy and showed no signs of rotting.

Analytical methods and isolation of hopanoids. Hopancid extraction and derivatization, qualitative GLC, quantitative GLC, GLC/MS, HPLC, ${ }^{1} \mathrm{H}$ - and ${ }^{13} \mathrm{C}-\mathrm{NMR}$ were performed as previously described (Peiseler \& Rohmer, 1991; Stampf $e t$ $a l$., 1991). As the amounts of hopanoids found during these investigations were expected to be low in the plant material examined, we utilized the most sensitive method, i.e. side-chain $\mathrm{H}_{5} \mathrm{IO}_{6} / \mathrm{NaBH}_{4}$ degradation of the bacteriohopanepolyols and derivatization for GIC analysis (Rohmer et al., 1984); the detection limit of this method for hopanoids lies around $0.1 \mu \mathrm{g}$ for each analysed fraction (Jürgens et al., 1992).

In order to obtain hopanoids with intact side-chains the crude chloroform/methanol extract was acetylated overnight at room temperature with acetic anhydride/pyridine $(1: 1, \mathrm{v} / \mathrm{v})$ (Renoux \& Rohmer, 1985). After removal of excess reagents under vacuum, the residue was thoroughly washed with toluene in order to selectively dissolve the acetylated hopanoids from poly$\beta$-hydroxybutyric acid, which is not soluble in this solvent. The toluene extract containing the peracetylated triterpenoids was separated by preparative TI.C (hand-made Merck 7744 silica gel plates, $1 \mathrm{~mm}$ thickness, cyclohexane/ethyl acetate, $2: 8, \mathrm{v}, \mathrm{v}$ ) giving less polar compounds $\left(R_{F}>0.80\right)$, octa-acetate of the bacteriohopanetetrol ether $\mathrm{V}\left(\mathrm{R}_{F}=0.70\right)$ and a fraction $\left(K_{F}=0 \cdot 60\right)$ which was further separated by TLC (cyclohexane/ethyl acetate, 4:6, v/v) giving the hepta-acetate of bacteriohopanetetrol ether $\mathrm{V}$ with a free tertiary hydroxy group $\left(R_{F}=0 \cdot 20\right)$ and the hepta-acetate of $O-\beta$-D-glucosaminyl- bacteriohopanetetrol VII $\left(R_{F}=0 \cdot 25\right)$. The less polar compounds $\left(R_{F}>0 \cdot 80\right)$ were further separated by TLC (methylene chloride) into tetra-acetate of bacteriohopanetetrol IV $\left(R_{F}=0.32\right)$ and a fraction containing diplopterol II and $2 \beta$ methyldiplopterol III $\left(R_{F}=0.44\right)$. The two latter compounds could be separated from one another by reverse-phase HPLC on a Dupont Zorbax ODS column $(250 \times 3.9 \mathrm{~mm}$, methanol/water, $96: 4, \mathrm{v} / \mathrm{v}, 1 \mathrm{ml} \mathrm{min}^{-1}$ ). Pure octa-acetate of the other bacteriohopanetetrol ether $\mathrm{V}$ could be obtained after a similar reverse-phase HPLC (methanol/water, 98:2, v/v, $1 \cdot 2 \mathrm{ml} \mathrm{min}^{-1}$ ).

All hopanoids were identified by comparison of their ${ }^{1} \mathrm{H}$ - and ${ }^{13}$ C-NMR spectra and/or GLC or HPLC retention times with those of reference compounds previously synthesized or isolated in this laboratory from Methylobacterium organophilum and Zymomonas mobilis (Renoux \& Rohmer, 1985; Bisseret et al., 1985; Flesch \& Rohmer, 1986).

\section{RESULTS AND DISCUSSION}

\section{Hopanoid content of the PPFMs}

Quantitative GLC analysis of the fractions arising from the chloroform/methanol extract, treated according to our side-chain cleavage procedure (Rohmer et al., 1984) showed that all the PPFMs contained appreciable amounts of hopanoids: diploptene I, diplopterol II, $2 \beta$-methyldiplopterol III (Fig. 1) and bacteriohopanepolyol derivatives as indicated by the presence of the acetate of the $\mathrm{C}_{32}$ bis-homohopanol (Table 1). From the acetylated chloroform/methanol extract hopanoids with intact side-chains could be isolated. Whereas the bacteriohopane derivative content of the SAL, CONO and CM strains (bacteriohopanetetrol IV, tetrol ethers $\mathrm{V}$ and $\mathrm{VI}$ and tetrol glycoside VII) was qualitatively identical with that reported from Metbylobacterium organophilum (Renoux \& Rohmer, 1985), only tetrol IV could be detected in the MIM-2 and MESO strains (Fig. 1). Furthermore if the 
Table 1. Hopanoid content ( $\mu \mathrm{g} \mathrm{g}^{-1}$, freeze-dried material) in PPFMs and plants as determined by weighing (II to VII) or GLC (I and $\mathrm{C}_{32}$ acetate obtained after $\mathrm{H}_{5} / \mathrm{O}_{5} / \mathrm{NaBH}_{4}$ treatment of the bacteriohopanepolyols)

\begin{tabular}{|c|c|c|c|c|c|c|c|}
\hline \multirow{2}{*}{$\begin{array}{l}\text { Biological } \\
\text { material }\end{array}$} & \multicolumn{2}{|r|}{$\mathrm{C}_{30}$} & \multicolumn{4}{|c|}{$\mathrm{C}_{35}$} & \multirow[b]{2}{*}{$\begin{array}{l}\text { Acetate } \\
\mathrm{C}_{32} \\
\text { alcohol }\end{array}$} \\
\hline & $\begin{array}{c}\text { Diploptene } \\
\text { I }\end{array}$ & $\begin{array}{l}\text { Diplopterol II } \\
\text { and } 2 \beta \text {-methyl } \\
\text { diplopterol III }\end{array}$ & $\begin{array}{c}\text { Tetrol } \\
\text { IV }\end{array}$ & $\begin{array}{c}\text { Ether } \\
\text { V }\end{array}$ & $\begin{array}{c}\text { Ether } \\
\text { VI }\end{array}$ & $\begin{array}{c}\text { Glycoside } \\
\text { VII }\end{array}$ & \\
\hline \multicolumn{8}{|l|}{ PPFMs } \\
\hline SAL & 200 & $4300(80 \%)^{*}$ & 2300 & 3600 & 900 & 500 & 5600 \\
\hline CONO & 700 & $3900(85 \%)^{*}$ & 1600 & 2600 & 300 & 200 & 3600 \\
\hline $\mathrm{CM}$ & 500 & $2400(90 \%)^{*}$ & 1500 & 1800 & 200 & 200 & 2300 \\
\hline MIM & 700 & $3600(55 \%)^{*}$ & 1000 & ND & ND & ND & 2100 \\
\hline MESO & 500 & $2800(60 \%)^{*}$ & 1000 & ND & ND & ND & 1900 \\
\hline PC1† & 200 & 600 & & & & & 900 \\
\hline \multicolumn{8}{|l|}{ Plants } \\
\hline Abietinella abietina & 6 & $+\ddagger$ & & & & & 6 \\
\hline Trifolium repens & 17 & ND & & & & & $0 \cdot 2$ \\
\hline Viola odorata & 6 & ND & & & & & 6 \\
\hline $\begin{array}{l}\text { Solanum } \\
\text { lycopersicum }\end{array}$ & ND & ND & & & & & ND \\
\hline Vitis vinifera & ND & ND & & & & & ND \\
\hline Fragaria vesca & ND & ND & & & & & ND \\
\hline Amaryllis sp. & ND & ND & & & & & ND \\
\hline
\end{tabular}

ND, Investigated but not detected.

* Relative amount of $2 \beta$-methyldiplopterol in the mixture of diplopterol and $2 \beta$-methyldiplopterol as determined by HPLC.

† Composite hopanoids of the PC1 strain have not been investigated.

$\ddagger$ Diplopterol and methyldiplopterol were detected by GLC/MS in the Osenbach sample only.

quantitative data obtained by the two methods of determination (GLC determination after $\mathrm{H}_{5} \mathrm{IO}_{6} / \mathrm{NaBH}_{4}$ side-chain derivatization or weighing of the intact acetylated bacteriohopanepolyol fractions) fit well together for the three former strains, isolation of intact acetylated hopanoids yields an apparent underestimation compared with the side-chain cleavage method (Table 1). This discrepancy between the values was reproducible. Even when larger amounts of cells $(15 \mathrm{~g}$ instead of $7 \mathrm{~g}$ dry weight for the MESO strain; $6 \mathrm{~g}$ instead of $2 \mathrm{~g}$ for the MIM-2 strain) were utilized for a second determination in order to minimize experimental errors, the same concentrations of diploptene, diplopterol, $2 \beta$-methyldiplopterol and bacteriohopanetetrol were found. This might point to the possible presence of hopanoids which are not extracted and/or not detected by our methods. Such forms, insoluble in organic solvents, are for instance known for carotenoids which form complexes with proteins (Thirkell \& Hunter, 1969; Schwencker et al., 1974) and hopanoids (Herrmann \& Rohmer, unpublished results). A bacteriohopanetetrol ether similar to ether VI could not be directly extracted from freeze-dried cells of an Acetobacter species, even after repeated treatment with chloroform/methanol $(2: 1)$ under reflux. Finally in PPFMs, as already observed for other bacteria, bacteriohopanepolyol content is largely dependent on the growth conditions and the composition of the culture medium (Renoux \& Rohmer, 1985; Bisseret $e$ t al., 1985; Zundel \& Rohmer, 1985; Rohmer \& Ourisson, 1986). After ten transfers, during three weeks, of the SAL and CONO strains from a complex to a minimal medium, the bacteriohopanepolyols IV, V, VI and VII could no longer be detected, the slightly higher diplopterol concentration ( 5.7 instead of $4.3 \mathrm{mg}$ per $\mathrm{g}$ dry weight) not compensating the loss of the composite hopanoids. Further transfer from minimal to complex medium restored the initial hopanoid composition where all bacteriohopane derivatives were present, showing that these changes were fully reversible.

\section{Taxonomic implications}

The taxonomic position of the PPFMs was for a long time rather uncertain and confused. Generic assignment to the genus Metbylobacterium was finally made on the basis of DNA:DNA homologies and phenotypic data (Green \& Bousfield, 1982, 1983; Bousfield \& Green, 1985; Hood $e t$ al., 1987). Corpe \& Jensen (1991) studied the distribution and localization of PPFMs on plant leaf surfaces. They used a specific antiserum prepared in rabbits against whole cells of the PPFM strain PC1 isolated from clover. Only cells of Metbylobacterium strains isolated from diverse 
sources developed an immunoreaction against this antiserum. Representative bacteria of other genera did not produce such reactions.

Analysis of the other PPFM hopanoids and comparison with those of the type culture of Methylobacterium organophilum were in accord with the classification of PPFMs within the genus Metbylobacterium. Indeed, M. organopbilum and the other PPFMs were found to be good hopanoid producers. They represent the only bacteria found to date that contain high concentrations of diplopterol II and/or $2 \beta$-methyldiplopterol III. The amounts found are usually around several $\mathrm{mg}$ per $\mathrm{g}$ dry weight. All other bacteria investigated show diplopterol concentrations of at least one order of magnitude lower (Rohmer et al., 1984; M. Rohmer, unpublished results). Furthermore, although $2 \beta$-methylbacteriohopanepolyols are common in cyanobacteria (Bisseret et al., 1985; Simonin, 1993), the presence of $2 \beta$-methyldiplopterol III seems to be restricted to $M$. organophilum and the other PPFMs. The bacteriohopanetetrol ether VI bearing a guanidium group on its carbapseudopentose moiety has been found only in $M$. organophilum and another three PPFMs. All results at the level of the triterpenic composition of these bacteria suggest they may be related, within or close to the genus Methylobacterium.

\section{Bacterial hopanoids in plant samples}

A major ecological niche of PPFMs is the phylloplane, i.e. the plant leaf surface. Leaves from several plant species and a moss were investigated for the presence of bacterial hopanoids. 3-Deoxyhopanoids have never been reported to occur in higher plants. Diploptene has been found in some mosses in amounts as high as $1 \mathrm{mg} \mathrm{g}^{-1}$, as reported by Marsili et al. (1972), but not bacteriohopane derivatives. In our results (Table 1) bacterial hopanoids (diploptene and bacteriohopanepolyol derivatives) were detected in two higher plant species: Trifolium repens, which was already known to possess numerous PPFMs on its phylloplane (Corpe \& Rheem, 1989), and Viola odorata. Two samples of the moss Abietinella abietina, which was already known to contain diploptene I (Marsili et al., 1972), both contained bacterial hopanoids (Table 1). This is the first report of bacterial triterpenoids being isolated from eukaryotic plants, but most probably not synthesized by these plants. The detection of derivatives with the $\mathrm{C}_{35}$ bacteriohopane skeleton characteristic for eubacteria, should represent the signature of symbiotic or epibiontic bacteria. In the other plants studied, no hopanoids could be detected. The hopanoid concentration might have been too low and/or their GLC and GLC/MS detection hampered by the large amounts of plant metabolites present in the hopanoid-containing fractions. Indeed the chromatograms of the fractions containing diplopterol or the bacteriohopanepolyols derivatives showed large peaks in the region corresponding to hopanoid retention times. We are left to conclude that hopanoid producers are simply absent or present in very small numbers in the samples investigated. At this stage of our knowledge of hopanoid distribution, the presence of bacterial hopanoids in plant extracts cannot be correlated with specific bacterial epibionts, but this method might prove to be useful for the detection of such hopanoid-producing micro-organisms from plant tissues or from other natural habitats.

\section{ACKNOWLEDGEMENTS}

This work was supported by the Centre National de la Recherche Scientifique (Unité de Recherche Associée 135). We acknowledge gratefully our debt to Dr P. Green (NCIMB, Aberdeen, UK) for the identification of the SAL strain, to Professor A. Gagnieux and M. V. Rastetter for the identification of the Abietinella abietina samples, and to Dr D. Le Nouen for all NMR measurements.

\section{REFERENCES}

Bisseret, P., Zundel, M. \& Rohmer, M. (1985). Prokaryotic triterpenoids. 2 $\beta$-Methylhopanoids from Metbylobacterium organophilum and Nostoc muscorum, a new series of prokaryotic triterpenoids. Eur J Biochem 150, 29-34.

Bousfield, I. J. \& Green, P. N. (1985). Reclassification of bacteria of the genus Protomonas (Urikami and Komagata, 1984) in the genus Metbylobacterium (Platt, Cole and Hanson) Emend Green and Bousfield, 1985. Int J Syst Bacteriol 35, 209.

Corpe, W. A. (1985). A method for detecting methylotrophic bacteria on solid surfaces. J Microbiol Metbods 3, 215-221.

Corpe, W. A. \& Basile, D. V. (1982). Methanol-utilizing bacteria associated with green plants. Dev Ind Microbiol 23, 483-493.

Corpe, W. A. \& Jensen, T. E. (1991). Major antigens in Metbylobacterium species and their location in cells using immunoelectron microscopic methods. Cytobios 67, 117-126.

Corpe, W. A. \& Rheem, S. (1989). Ecology of the methylotrophic bacteria on living leaf surfaces. FEMS Microbiol Ecol 62, 243-250.

Corpe, W. A., Jensen, T. E. \& Baxter, M. (1986). Fine structure of cytoplasmic inclusions of some methylotrophic bacteria from plant surfaces. Arch Microbiol 145, 107-112.

Flesch, G. \& Rohmer, M. (1986). A novel hopanoid from the ethanol-producing bacterium Zymomonas mobilis. Biochem $J$ 262, 673-675.

Flesch, G. \& Rohmer, M. (1988). Prokaryotic hopanoids: the biosynthesis of the bacteriohopane skeleton. Formation of isoprenic units from two distinct acetate pools and a novel type of carbon/carbon linkage between a triterpene and D-ribose. Eur $J$ Biochem 175, 405-411.

Green, P. N. \& Bousfield, I. J. (1982). A taxonomic study of some Gram-negative facultatively methylotrophic bacteria. J Gen Microbiol 128, 623-638.

Green, P. N. \& Bousfield, I. J. (1983). Emendation of Methylobacterium (Patt, Cole and Hanson, 1976); Metbylabacterium rbodium (Heumann, 1962) comb. nov. corrig; Metbylobacterium radiotolerans (Ito and Izuha, 1971) comb. nov. corrig., and Metbylobacterium mesophilicum (Austin and Goodfellow, 1979) comb. nov. Int J Syst Bacteriol 33, 875-878.

Green, P. N., Bousfield, I. J. \& Hood, D. (1988). Three new Metbylobacterium species: $M$. rbodesianum sp. nov., $M$. zatmanii sp. nov., $M$. fujisawaense sp. nov. Int J Syst Bacteriol 38, 124-127.

Hestrin, S. \& Schramm, M. (1954). The synthesis of cellulose by Acetobacter xylinum. Biocbem J 58, 345-352.

Hood, D. W., Dow, C. S. \& Green, P. N. (1987). DNA:DNA hybridization studies of the pink-pigmented, facultative methylotrophs. J Gen Microbiol 133, 709-720.

Jürgens, U. V., Simonin, P. \& Rohmer, M. (1992). Localization and 
distribution of hopanoids in membrane systems of the cyanobacterium Synechocystis PCC 6714. FEMS Microbiol Lett 92, 285-288.

Marsili, A., Morelli, I., Bernardin, C. \& Pacchiani, M. (1972). Constituents of some mosses. Pbytochemistry 11, 2003-2005.

Ourisson, G., Albrecht, P. \& Rohmer, M. (1979). The hopanoids, paleochemistry and biochemistry of a group of natural products. Pure Appl Chem 51, 709-729.

Peiseler, B. \& Rohmer, M. (1991). Prokaryotic triterpenoids. (22R,32R)-34-35-Dinorbacteriohopane-32,33-diols from Acetobacter aceti ssp. xylinum: new bacteriohopane derivatives with shortened side-chain. J Chem Soc Perkin I, 2449-2453.

Renoux, J. M. \& Rohmer, M. (1985). Prokaryotic triterpenoids: new bacteriohopanetetrol cyclitol ethers from the methylotrophic bacterium Methylobacterium organophilum. Eur J Biocbem 151, 405410.

Rohmer, M. \& Ourisson, G. (1986). Unsaturated bacteriohopanepolyols from Acetobacter aceti ssp. xylinum. J Chem Res (S) 356-357, (M) 3037-3059.

Rohmer, M., Bouvier-Navé, P. \& Ourisson, G. (1984). Distribution of hopanoid triterpenes in prokaryotes. J Gen Microbiol 130, 1137-1150.

Rohmer, M., Sutter, B. \& Sahm, H. (1989). Bacterial sterol surrogates. Biosynthesis of the side-chain of bacteriohopanetrol and of a carbocyclic carbapseudopentose from ${ }^{13} \mathrm{C}$ labelled glucose in Zymomonas mobilis. J Chem Soc Chem Commun 1471-1472.

Rohmer, M., Knani, M., Simonin, P., Sutter, B. \& Sahm, H. (1993). Isoprenoid biosynthesis in bacteria: a novel pathway for the early steps leading to isopentenyl diphosphate. Biochem J 295, 517-524.

Schwencker, U., Onge, M. S. \& Gingras, G. (1974). Chemical and physical properties of a carotenoprotein from $R$ bodospirillum rubrum. Biochim Biophys Acta 351, 246-260.

Simonin, P. (1993). Nouvelle voie de biosynthèse des isoprénoïdes chez les bactéries. Biobopanoïdes bactériens. Thèse, Université de Haute Alsace, Mulhouse, France.

Stampf, P., Herrmann, D., Bisseret, P. \& Rohmer, M. (1991). $2 \alpha-$ Methylhopanoids: first recognition in the bacterium Metbylobacterium organophilum and obtention via sulphur induced isomerization of $2 \beta$-methylhopanoids. Tetrabedron 34, 7081-7090.

Thirkell, D. \& Hunter, M. I. S. (1969). Carotenoid-glycoprotein of Sarcina flava membrane. J Gen Microbiol 58, 289-292.

Zundel, M. \& Rohmer, M. (1985). Prokaryotic triterpenoids: 3 $\beta$ methylhopanoids from Acetobacter species and Metbylococcus capsulatus. Eur J Biochem 150, 23-27.

Received 1 March 1994; revised 19 May 1994; accepted 25 May 1994. 